\title{
Between Consensus, Consolidation and Crisis: Immigration and Integration in 1970s Britain
}

Entre consensus, consolidation et crise: immigration et intégration en Grande-

Bretagne dans les années 1970

\section{Vincent Latour}

\section{(2) OpenEdition}

\section{Journals}

Electronic version

URL: http://journals.openedition.org/rfcb/1719

DOI: $10.4000 /$ rfcb. 1719

ISSN: 2429-4373

Publisher

CRECIB - Centre de recherche et d'études en civilisation britannique

Electronic reference

Vincent Latour, « Between Consensus, Consolidation and Crisis: Immigration and Integration in 1970s Britain », Revue Française de Civilisation Britannique [Online], XXII- Hors série | 2017, Online since 30 December 2017, connection on 19 April 2019. URL : http://journals.openedition.org/rfcb/1719 ; DOI : $10.4000 /$ rfcb. 1719

This text was automatically generated on 19 April 2019

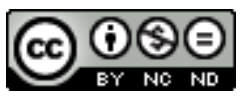

Revue française de civilisation britannique est mis à disposition selon les termes de la licence Creative Commons Attribution - Pas d'Utilisation Commerciale - Pas de Modification 4.0 International. 


\title{
Between Consensus, Consolidation and Crisis: Immigration and Integration in 1970s Britain
}

Entre consensus, consolidation et crise: immigration et intégration en GrandeBretagne dans les années 1970

\author{
Vincent Latour
}

1 The 1970s have often been considered in relation to other decades. Andy Beckett, though not necessarily sharing that perception himself, calls the "turbulent" 1970s "a hangover from the 1960s", whereas others consider them as a decade of downright decline, dominated by the notion of crisis, the final decade of the post-war consensus which was shattered by Margaret Thatcher and the New Right in the 1980s. However, the 1970s were also characterised by a number of experiments, failures but also sometimes achievements, which contributed to shaping late $20^{\text {th }}$ and early $21^{\text {st }}$ century Britain. It is the aim of this article to establish and document to what extent this applies to the questions of immigration and integration.

2 Alongside the omnipresent and multifaceted notion of "crisis", the weight of the post-war consensus was clearly felt throughout much of the decade, although various forces were already at work to undermine it.

3 Part one will show that the immigration legislation put in place in the 1970s reflected to a very large extent the state of public opinion since the 1960s at least and was the result of a broad cross-party consensus on the need to control immigration, despite the existence of critical, divisive episodes, such as the Ugandan refugee crisis.

4 Part two will turn to state intervention regarding integration and racism. As will be documented, on the one hand the 1970s saw the consolidation and the extension of the Race Relations legislation framework devised in the mid-1960s and on the other hand, the persistence of ordinary racial prejudice and the rise of violent racism.

5 Part three, finally, will turn to migrant groups, politics and crises. It will investigate and document the attitude of the main two parties towards immigrants, as well as the specific 
forms of immigrant mobilisation - whether particularist or not - that took shape in the 1970s, both inside and outside mainstream political parties and unions.

\section{Immigration: consensus and crisis}

\section{A Broad Consensus on Immigration Control}

6 In June 1970, when Edward Heath took over as Prime Minister, Britain had already put an end to mass economic immigration from the New Commonwealth, not because the country did not need migrant workers, but because their presence had aroused anxiety and resentment among vast swathes of the British population for the past two decades. However, this had meant neither the end of immigration, nor the end of the explosiveness of the issue. Indeed, the 1962 Commonwealth Immigrants Act, passed under Harold Macmillan's Conservative government, signalled the beginning of a new phase of immigration, namely family reunification, which changed Britain's ethnic, cultural and religious profile far more than economic immigration in the fourteen years between 1948 and 1962. Until 1962, New Commonwealth immigrants had chiefly been men, comparatively few of whom settled firmly in the UK. Fears of impending tightened immigration controls meant that family reunion gathered momentum in the one and a half decades that followed the 1962 Act, all the more so as family reunion had been guaranteed by the European Social Charter since 1961 (through Article 19, notably). ${ }^{1}$

Throughout the 1960s and much of the 1970s, thousands of Indian, Pakistani or Jamaican men were therefore joined by their wives, children (and not infrequently in the case of Asians, other dependants). As a result, the numbers of New Commonwealth immigrants rose sharply. In 1971, there were for example 313,00 Indians (as against 157,000 in 1961); 171,000 Jamaicans (as against roughly 100,000 in 1961); 136,000 Pakistanis and 58,000 Kenyans (neither Pakistan nor Kenya were part of the top ten non-UK countries of birth in 1961). It is to be noted that Irish immigration remained remarkably stable throughout the period (676,000 in 1971, as against 683,000 in 1961). ${ }^{2}$

8 Even before assuming office in June 1970, Edward Heath had acquired a reputation as a moderate on immigration and what was then known as "race relations", which was consistent with his "one nation" profile, one nation Conservatism being the dominant vision within the Tory party until Margaret Thatcher took over as leader in 1975. That reputation had been shaped by the firmness he had displayed as Conservative leader towards Enoch Powell when the then Shadow Home Secretary delivered his inflammatory "Rivers of Blood Speech" in $1968^{3}$, an episode evoked in retrospect by a somewhat selfsatisfied Heath in his memoirs, published in 1998:

It what against that volatile background that as Prime Minister I set about trying to improve the situation [...] Between 1968 and 1970, my mailbag had contained many letters, largely from Conservative supporters, in support of Enoch Powell. They were frequently abusive, towards me as much as towards black people, but this only made me more resolute. There were certainly those in the party, even on the front bench, who wanted to harness racist support. Some commentators have argued that I bowed to this pressure and that, as a result, Powell helped me to win the election of 1970 just as he helped Wilson to defeat me in 1974 on the question of Europe. I totally disagree. ${ }^{4}$

9 During the 1970 general election campaign, despite Heath's moderate, centrist approach ${ }^{5}$, Conservatives had pledged that there would "be no further large-scale permanent 
immigration". This led to the introduction of the 1971 Immigration Act, which, again, specifically targeted non-white immigration, by establishing a distinction between " patrials" (those born in the UK or one of its remaining colonies or with a parent or a grandparent born in the UK, i.e. Canadians, New Zealanders or Australians, for example) and non-patrials. "Patrials" alone had the unconditional right to settle in the UK, while non-patrials (e.g. Pakistanis, Indians, Jamaicans) had to apply for work permits, granted only to those whose skills were in short supply in Britain. Non-patrials were, moreover, subject to the non-renewal of their permit. ${ }^{7}$ According to Dominic Sandbrook, that piece of legislation was meant to "bring up the drawbridge", an objective that did not so much reflect the personal views of most members of the government as it was meant to soothe public opinion, as immigration remained the biggest potential election loser, seven years after the Smethwick by-election ${ }^{8}$ and three years after Powell's infamous speech:

[...] Reginald Maulding told his colleagues that since assimilation was "all but impossible" for Asians, immigration ought to be limited to people "from a cultural background fairly akin to our own'. But Heath's ministers were by and large, a liberal-minded lot, and certainly more tolerant than the rest of the population. They closed the door to mass immigration not because they were racist reactionaries, but because public opinion - as manifested in one poll after another demanded it. ${ }^{9}$

10 Almost three decades later, Heath presented the 1971 Immigration Act as a moderate piece of legislation and rejected the idea that it might be considered racist:

It is true that we promised to limit immigration in our manifesto, but we did so as part of the balanced approach to the problem [...] I could not have made clearer to voters that there would be no Faustian pact with Powell and that racism would get no encouragement of any kind from the Conservative Party, so long as I was its leader. ${ }^{10}$

\section{The Ugandan Asian refugee crisis and the Tory Right}

11 In August 1972 Heath's reputed moderation was put to the test by a major crisis: the expulsion of thousands of so-called "East African Asians"11 from Uganda, as a result of the implementation of Africanization policies in the former British colony. Dictator Idi Amin gave them one month to leave. ${ }^{12}$ As Heath wrote in his memoirs: "Uganda was still part of the Commonwealth and we therefore had a moral duty to accept these unfortunate people."13 28,000 of the country's 57,000 Asians settled in Britain in total, after a Uganda Resettlement Board (URB) was set up, as announced by Foreign Secretary Alec DouglasHome in a TV broadcast on 31 August 1972. The aim of the URB was to designate a certain number of Local Authorities (usually those with comparatively few New Commonwealth immigrants) that would then be advised by the central government in order to help Ugandan Asians settle in the country. Again, Heath had to face to opposition from Tory right-wingers. "This was led by Enoch Powell, and some sections of the media joined in the ugly chorus" ${ }^{14}$, Heath writes in his memoirs. In the following weeks, the Monday $\mathrm{Club}^{15}$ launched a "Halt Immigration Now" campaign, which culminated at the Conservative Party Conference in October 1972, Powell arguing that Britain had no moral obligations towards Ugandan Asians and that therefore they should not be accepted. Powell and his like were nevertheless defeated, thanks to the support of the Federation of Conservative Students and to the young Conservatives. ${ }^{16}$

12 However, the 1971 Act contained one provision, voluntary repatriation (section 29), which did seem to be a concession to Tory right-wingers, as repatriation had been 
advocated three years before by Enoch Powell in his notorious speech. The 1970 Conservative manifesto, however, rejected altogether compulsory repatriation, which Powell and the Monday Club repeatedly advocated before the general election. Powell, who used the term "re-immigration" in his 1968 speech, went so far as to recommend the creation of a "Ministry of repatriation" in the early $1970 \mathrm{~s}^{17}$. The Monday Club deemed that the scope of repatriation scheme set up by the government was insufficient: “ [...] Repatriation provisions seem to be limited to their expenses of return. Unless that can include resettlement, the response may not be as large as it should be." ${ }^{18}$ Voluntary repatriation did seem to be a token aspect of the 1971 Act, as admitted in 1973 by Robert Carr, the then Home Secretary (1972-1974):

I still think that assistance with repatriation is an important service to make available to those who wish to go back. (...) I accept that the pressure created by it is quite small in relation to other social and economic pressures, which at any given moment tend to cause major flows inwards and outwards. ${ }^{19}$

13 It actually is very difficult to obtain reliable data about the number of immigrants that actually used the scheme, but it does seem that its impact was minimal. In her PhD thesis, Catherine Puzzo thus writes that 62 families only benefited from the scheme between 1971 and 1973 (i.e. a total of 216 people) ${ }^{20}$, to be contrasted with the 60,000 guest workers plus 34,000 dependants (60 per cent of whom were from Spain and Portugal) who benefited from a similar scheme in France between 1977 and 198. ${ }^{21}$

The present author tried to obtain information from the Home Office and significantly enough got the following reply:

Your request has been handled as a request for information under the Freedom of Information Act 2000 [...] I have consulted the areas of the department which would be most likely to hold the information you have requested, however my enquiries have come back negative. Therefore I have concluded that the Home Office does not hold the information which falls within scope of your request [...]. ${ }^{22}$

On the whole, Labour and Liberal opposition to the 1971 Immigration Act was minimal (as underlined by Heath in his memoirs ${ }^{23}$ ) thus illustrating a consensus between the Conservative (1970-1974) and Labour (1974-1979) governments on the need to restrict both primary and secondary immigration. Kenneth 0 . Morgan notes that James Callaghan was "unsentimental" about restricting immigration, an issue "to be handled in a way attuned to public opinion rather than on the basis of an abstract liberal political theory." ${ }^{24}$

16 The next point will discuss whether a tacit consensus existed on the question of integration too.

\section{Integration, racism and state intervention}

17 Given the nature of post-war immigration, the correlated issue was "race". In his memoirs, Heath does not dodge the hostility displayed by the majority population, which, in a typically British manner, he attributes to large-scale immigration:

When I came to power, race was already a major source of conflict in Britain. Labour's 1948 British Nationality Act had granted British citizenship to all people in Commonwealth countries past and present and it was this that facilitated immigration in the 1950s. The racial prejudice that these immigrants encountered culminated in the Notting Hill race riots of 1958. Continuing inter-racial friction eventually prompted Rab Butler to bring in the Commonwealth Immigration Act in 1962 to limit the numbers of non-white immigrants by means of an employment 
voucher scheme. Although discriminatory in practice, the principle behind it was to give white Britons time to adjust to new arrivals and, thereby, to give existing immigrants and their descendants more of a chance to integrate. ${ }^{25}$

\section{The consolidation of Race Relations Legislation} five years, the country had been endowed with a liberal, modern-day integration policy, thus defined by Roy Jenkins, the then Labour Home Secretary in 1966:

\begin{abstract}
Integration is perhaps a rather a loose word and I do not regard it as meaning the loss, by immigrants, of their own natural characteristics and culture. I do not think we need in this country a 'melting pot', which will turn everyone out in a common mould, as one of a series of carbon copies of someone's misplaced vision of a stereotyped Englishman [...] I define integration, therefore, not as a flattening process of uniformity, but cultural diversity, coupled with equality of opportunity, in an atmosphere of mutual tolerance. ${ }^{26}$
\end{abstract}

19 Although Jenkins' definition was rather vague, it clearly distinguished integration in Britain from both American and French-style assimilation and it welcomed the expression of cultural differences. That liberal interpretation of integration was accompanied by the completion of the race relations legislation that the Wilson governments had started framing in the mid and late 1960s (1965 and 1968 Race Relations Acts).

Edward Heath did not question the approach devised by his predecessor. In the debate to the Queen's speech on 2 July 1970, Heath pledged to ensure:

[...] justice to all those who are already in the country, whatever their race, creed or colour may be, to set the public mind at rest on this issue so that there cannot be any further justification for existing passions and so that they can be absolutely no reason for apprehension on the part of immigrants who are already settled here. ${ }^{27}$

The Conservative government however did not go so far as to strengthen the existing race relations legislation, despite its disappointingly poor record. Indeed, out of the 2,967 complaints investigated by the Race Relations Board (a watchdog set up under the 1965 Race Relations Act) between 1965 and 1972, seven only resulted in court cases: five verdicts were reached, two were lost, thus resulting in a conviction rate of 0.1 per cent. ${ }^{28}$ Imagined under Harold Wilson's government, the third Race Relations Act was passed in 1976, under James Callaghan, who took over as Labour Prime Minister (1976-1979) after Wilson resigned, for health reasons ${ }^{29}$, it emerged later. The 1976 Race Relations Act was passed a few months after the publication of a white paper on racial discrimination (September 1975), which came to the conclusion that urgent but realistic action was required and that both the central government and local authorities should set the example:

14. The review of race relations undertaken in the past year has convinced the Government that if urgent action is necessary, it is even more necessary to devise policies which are coherent rather than spectacular, to set targets which are relevant and realisable rather than dramatic. The gravity of the prospect demands action, but it places a premium on carefully considered action, consistently carried through. Nothing at this juncture could be worse than bold promises without the means of implementation.

15. The Government has a special responsibility as an employer. An unequivocal statement of the Government's equal opportunity policy has been made to all Departments covering all grades and positions in both the industrial and the non- 
industrial Civil Service. The policy states, with the full support of staff representatives, that there will be no discrimination against any person eligible under the nationality rules whether in recruitment, training or promotion or in any other way, on the grounds of colour, race, ethnic or national origins. ${ }^{30}$ may be described as equal in a formal sense may be discriminatory in its effect on one particular racial group) and made provisions for positive discrimination: local authorities were encouraged to "to make appropriate arrangements" (a) "to eliminate unlawful racial discrimination" and (b) "to promote equality of opportunity, and good relations, between persons of different racial groups". ${ }^{31}$ New Commonwealth immigrants and their descendants, who formed the bulk of Britain's non-white population, were now theoretically placed under the full protection of law, which was long overdue. Indeed, it appears that in the 1970s Britain, Asian or Afro-Caribbean immigrants were still characterised, by and large, by social relegation, or indeed, invisibility. As explained in 1999 by Jack Howard-Drake, Assistant Secretary at the Home Office under Wilson's and Heath's Premierships, New Commonwealth immigrants were employable provided they were not in touch with the public, a situation that prevailed in many private sector firms until the mid 1970s, at least:

[...] [employers] were quite happy to employ coloured people but providing they were not visible. In other words, if they worked in the kitchens, that was alright, but employers felt that shoppers wouldn't like to see coloured hands handling food over the counter. They thought that ladies wouldn't be happy to buy their underwear from coloured girls. ${ }^{32}$

In addition, the 1976 Race Relations Act created a new body, the Commission for Racial Equality (CRE), which replaced the old Race Relations Board. Although the scope of the Act was in theory far greater than that of the previous two ones and tackled for the first time the issue of racial segregation, it was criticised on the ground of its comparative inefficiency. In Andy Beckett's study, Ambavalaner Sivanandan, a leading figure at the Institute of Race Relations (a think-tank created in 1958) is quoted saying: "The 1976 Race Relations Act had no teeth. Never mind no teeth, it had no gums." ${ }^{33}$ By the end of 1978, only twenty-nine cases of racial discrimination had been investigated by the CRE, with merely one concluded ${ }^{34}$ a record reminiscent of that of the previous watchdog, the Race Relations Board.

\section{The persistence of "ordinary" racial prejudice and the rise of violent racism}

Racial prejudice remained widespread. This was especially true in the judicial system, two decades before the notion of "institutional racism" was documented by the Stephen Lawrence inquiry. ${ }^{35}$ In 1970, there were only 10 non-white policemen in London. The campaign launched by Robert Mark (Commissioner of the Metropolitan Police from 1972 to 1977) to recruit black recruits in the Met failed to improve the situation, with 70 nonwhite officers in 1976 (out of a workforce of 22,000), ${ }^{36}$ the year of the Notting Hill Carnival riots, ${ }^{37}$ which took the shape of serious street clashes, thus prefiguring the inner city riots of the 1980s.

The other components of the judicial system were also overwhelmingly white and testified to the existence of a clear racial bias. This was obvious in courts and prisons. In 1978, John Kinglsey Read, a one-time member of the Conservative Party who then joined 
the National Front, was tried at the Old Bailey for incitement to racial hatred for declaring, after the murder of a Sikh man in Southall: "One down, a million to go". Judge Neil MacKinnon ruled that it undeniably was an insult to a dead man but that it did not constitute an insult in itself. MacKinnon multiplied controversial statements throughout the trial, suggesting for example that "nigger" was not a term of abuse or that "the black man wanted to follow the white man to Britain" [because of] the affection engendered" by the British imperial legacy. ${ }^{38}$ Kingsley Read was acquitted by the all-white jury. Following the trial, Turner writes, twenty non-white barristers refused to work with Judge McKinnon, while 133 MPs signed a motion for him to be fired, despite the strict tradition of the separation of powers. ${ }^{39}$ It should be underlined however that the although Kingsley Read trial had taken place two years after the passing of the 1976 Race Relations Act, the verdict came just a few days before the new Act came into force, which means that Kingsley Read was actually tried under the 1965 and 1968 Acts. In addition, Turner writes that racial prejudice was at its worst in jails, with many prison officers sympathetic to the National Front, including chaplains, as was the case, notoriously, at Brixton prison. ${ }^{40}$

Outside the judicial system, racial tensions were on the rise, with 36 racially motivated murders between 1976 and 1981, the majority of which took place in East London and the Midlands. The rise of violent racism and the comparative electoral successes of the National Front (until 1979) prompted the creation of the Anti-Nazi League (ANL), launched in 1976 following a press conference held in the House of Commons under the aegis of Labour MP Neil Kinnock. The driving force behind, however, was the Socialist Workers' Party, whose influence could also be felt in Rock Against Racism, a series of accompanying concerts involving punk, reggae or new wave bands. ${ }^{41}$

However the general picture of race relations in 1970s Britain was not so grim. Racial tensions existed in other countries too, in France notably, where North Africans were the primary targets of brutal racist attacks. Thus, between March and July 1971 alone, eight Algerians were killed, in Lyons, mostly. Tensions were particularly obvious in Marseilles too, where seven North Africans were killed in August 1973. Later that year, in the tense context of the Yom Kippur War, a bomb attack targeted the Algerian consulate in Marseilles, killing four people, which prompted President Pompidou to declare that France was "a deeply antiracist country".

Moreover, the anti-discriminatory legislation that existed in the 1970s was well ahead of its time and made Britain a truly unique country in Europe. By contrast, a comparatively low-key law had been passed in July 1972 in France to outlaw incitement to racial discrimination, hatred and violence, as well as to prevent the expression of racist ideas in the press. For all its merits, it did not match in any way the scope of Britain's race relations legislation. ${ }^{42}$

The pro-active British approach of the 1970s paved the way for the multiculturalist policies of the 1980s and 1990s. Although Britain factually was "multicultural" by the 1970s (in the descriptive acceptation of the term), the terms "multicultural" and " multiculturalism" were unheard of in 1970s Britain. It was not until the turn of the 1980s that they started emerging, mostly in activist and academic circles at first, despite what is sometimes suggested. ${ }^{43}$ 


\section{Migrant Groups, Politics and Crises}

\section{Mainstream Political Parties and immigrants}

After Margaret Thatcher took over as Conservative leader, the Conservative Party moved away from its one nation approach. This applied to immigration and race relations too: the Tories' anti-immigration and assimilationist stances became increasingly clear. This was of course reinforced by Margaret Thatcher's rhetoric of invasion, deployed during a TV interview for World In Action (Granada, 1978):

[...] Let us try and start with a few figures as far as we know them, and I am the first to admit it is not easy to get clear figures from the Home office about immigration, but there was a committee which looked at it and said that if we went on as we are then by the end of the century there would be four million people of the new Commonwealth or Pakistan here. Now, that is an awful lot and I think it means that people are really rather afraid that this country might be rather swamped by people with a different culture and, you know, the British character has done so much for democracy, for law and done so much throughout the world that if there is any fear that it might be swamped people are going to react and be rather hostile to those coming in. ${ }^{44}$

Unsurprisingly, the appeal of the Conservative Party among New Commonwealth immigrants was at best very limited, although John Solomos does underline that in certain constituencies there were attempts at wooing the Asian electorate, whose views on free enterprise, family or religious values seemed to converge with Thatcher's. The Labour Party was still perceived as the immigrants' natural party, notably owing to its decisive role in framing race relations legislation. In the 1974 and 1979 general elections, the vast majority of New Commonwealth immigrants voted Labour. The Labour Party Race Action Group was a pressure group created in 1975 within Labour. Its aim was to " raise awareness of the politics of racism within the party", as underlined by John Solomos. ${ }^{45}$ It was a comparatively successful attempt and prepared the ground for the radical measures put in place in the early and mid-1980s in Labour-run councils (e.g. contract compliances) or indeed the controversial black sections.

\section{Specific immigrant mobilisation inside and outside mainstream Political Parties}

33 John Solomos argues that in the 1970s, pretty much like in the 1960s, there appeared in Britain "a variety of different forms of autonomous organisation in a number of different contexts rather than unified ethnic movements". ${ }^{46}$ As a matter of fact, what few nation-wide movements did emerge rarely stretched beyond the limits of strictly defined communities. The situation of British Sikhs is a case in point. Despite their previous involvement in various bus disputes throughout the country with Afro-Caribbeans and other immigrants from the Indian subcontinent (notably in Bristol in 1963), Sikhs continued, on the whole, to pursue a particularist agenda, after the successes of the first turban campaign of the 1960s. In the 1970s this resulted in the second turban campaign, which went on for three years (1973-1976). Sikhs opposed a new law, which made it compulsory, as from 1 June 1973, for motorcyclists to wear crash helmets (Section 32 of the Road Traffic Act 1972). The Act's implication was that Sikh motorcyclists would be required to remove their turbans. Like the previous and the following campaigns, it was 
chiefly managed by the Gudwara networks throughout the country. At the 1974 general election, a Sikh man unsuccessfully stood as a single-issue candidate in Ealing. Harold Wilson's Labour Government eventually granted Sikhs an exemption (Motor-Cycle Crash Helmets [Religious exemption] Act 1976). Later in 1978, under Callaghan, the third turban campaign began: the Mandla case, which was to end in 1983 with a ground-breaking House of Lords decision, recognising Sikhs both an ethnic and a religious group. Despite their narrow focus, Gurharpam Singh and Darsham Singh Tatla argue that these campaigns had a broader, national impact, as they put the recently created antidiscriminatory legislation to the test and as such, contributed to shaping what was to become British multiculturalism. ${ }^{47}$

Although Muslim cultural and religious demands were to be formulated on a large scale in the 1980s with the rise of political Islam, notably following the publication of Rushdie's Satanic Verses (1988), some particularist grievances started emerging in the 1970s. In 1977, the Union of Muslim Organizations wrote to the Home Secretary to ask that halal food be served in schools and canteens with significant numbers of Muslims. Other grievances included for example provisions for prayer time or prayer rooms and the incorporation of elements of the Islamic law for the country's Muslims (around one million then). ${ }^{48}$

Sporadically, however, there emerged local movements that rallied a wide range of supporters. One case in point was the Grunwick dispute (1976-1978). Grunwick was a North West London photo-developing business, one of the largest in Britain, with roughly 500 employees. Certain departments, such as the mail order department, were almost exclusively staffed by Asian women, mostly from Kenya and Uganda. ${ }^{49}$ The company would not recognise the right of its employees to be represented by unions and only made provisions for a "works committee", set up in $1975.5^{50}$ The question of the representation of workers was all the more problematic as the workload intensified. Compulsory overtime was imposed on workers and working conditions deteriorated during the summer of 1976 , one of the hottest in the $20^{\text {th }}$ century. Tensions and incidents between the mostly Asian employees and the management multiplied, with the firing of several employees. On Monday 23 August 1976, Jayaben Desai, an East African Asian, and five of her colleagues mounted a picket and collected signatures for a petition. By midafternoon, about fifty Grunwick workers had joined the picket line. In the following weeks and months, the dispute intensified, with clashes between some employees or their left-wing supporters (members of the Communist Party or the Socialist Workers' Party, notably) and the Metropolitan police.

The dispute received extensive coverage from the national media, which spoke about the "strikers in saris", while Grunwick strikers got support letters from China or the US. On 30 June 1977, the Callaghan government - three members of which, Shirley Williams, Denis Howell and Fred Mulley had briefly joined the picket line one month earlier commissioned the Scarman Inquiry. Public hearings took place during the summer and at the end of August Lord Scarman disclosed his conclusions: unions should be recognised and the employees that had been fired should be re-instated. ${ }^{51}$ Nevertheless, the employer, supported by Thatchers' Conservatives and groups like the National Association For Freedom (a libertarian, law and order association launched in December 1975 by right-wing Tories, such as writer and television presenter Norris McWhirter and Viscount de l'Isle ${ }^{52}$, a former Governor General of Australia) rejected the advice. The TUC threw in the towel and the workers' strike committee announced the end of the dispute in June 1978. 

chiefly non-white protagonists that received widespread support from the labour movement, both from within the Labour Party and from alternative or far-left political organisations.

\section{Conclusion} the 1970s endeavoured to respond to racial discrimination, both in employment and housing and paved the way for the equal opportunity policies of the 1980s and 1990s. The 1976 Race Relations Act was a unique piece of legislation in Europe when it was introduced. It was well-ahead of its time and provided a framework for fighting racial discrimination and fostering equal opportunity for the next three and half decades, until it was superseded by the 2010 Equality Act.

41 Finally, the visible acceleration of migrant community mobilisation in the 1970s, announced the greater visibility and coordination (though not necessarily the greater success) of ethnic minority mobilisation in the 1980 s (e.g. Afro-Caribbean cultural and economic demands during the urban riots of the Thatcher era; the rise of Muslim cultural demands), in the context of the shift towards multiculturalist policies in the United Kingdom.

Therefore, the perception of the 1970s as, essentially, a decade of transition and decline can and should be challenged, at least when it comes to immigration and integration.

Vincent Latour est Professeur des Universités en civilisation britannique à l'Université Toulouse Jean Jaurès et membre de l'équipe CAS (EA 801). Ses travaux (monographie, articles, chapitres, ouvrages collectifs), souvent comparatistes, portent sur les politiques d'immigration et d'intégration au Royaume-Uni, en France et en Europe.

\section{BIBLIOGRAPHY}

"Heath vs Wilson - The 10 Year Duel" BBC 4, 2011 <https://www.youtube.com/watch?

$\mathrm{v}=\mathrm{j} Y N c L J W y l W U>$

Revue Française de Civilisation Britannique, XXII- Hors série | 2017 
« Race Relations Act 1976 (Repealed) »<http://www.legislation.gov.uk/ukpga/1976/74/section/3

$>$

The European Social Charter (1961) Article 19 " The right of migrant workers and their families to protection and assistance" <http://polis.osce.org/library/f/2667/466/CoE-ITA-RPT-2667-

EN-466.pdf>

The National Archives, Office for National Statistics, « Non-UK Born Census Populations 1951 2011 - Full infographic ». <http://webarchive.nationalarchives.gov.uk/20160105160709/http:// www.ons.gov.uk/ons/rel/census/2011-census-analysis/immigration-patterns-andcharacteristics-of-non-uk-born-population-groups-in-england-and-wales/non-uk-born-censuspopulations-1951---2011---full-infographic.html >

White Paper on Racial Discrimination" (PDF of the original document 1975) <http:// filestore.nationalarchives.gov.uk/pdfs/small/cab-129-184-c-93.pdf>

FUCHS, Gérard, Ils resteront : le défi de l'immigration (Paris, Syros, 1987).

HEATH, Edward, The Course of My Life (London, Hodder and Stoughton, 1998).

LATOUR, Vincent, "Voluntary repatriation / Aide au retour volontaire : la question du retour des immigrés au Royaume-Uni et en France dans les années 1970” in Dornel, Laurent (ed.), Le Retour (Pau, Presses Universitaires de Pau et des Pays de l'Adour, 2017) (number of pages unknown yet).

MACPHERSON, William, Report of an Inquiry by Sir William Macpherson of Cluny Presented to Parliament by the Secretary of State for the Home Department by Command of Her Majesty, (London, February 1999), <https://www.gov.uk/government/uploads/system/uploads/attachment_data/ file/277111/4262.pdf>

MORGAN, Kenneth Owen, Callaghan: A Life, Oxford (Oxford University Press, 1997)

Playing the Race Card, BBC 2, 1999 <https://www.youtube.com/watch?v=UMa1Zht0934>

SANDBROOK, Dominic, Seasons in the Sun. The Battle for Britain, 1974-1979 (London, Penguin, 2013).

SANDBROOK, Dominic, State of Emergency. The way we were : Britain 1970-1974 (London, Penguin, 2011).

SOLOMOS, John, Race and Racism in Britain (Basingstoke, Macmillan, 1993).

Thatcher, Margaret, TV Interview for Granada World in Action, 27 January 1978. Transcript available on the Margaret Thatcher Foundation website <http://www.margaretthatcher.org/ document/103485>

TURNER, Alwyn W., Crisis? What Crisis ? Britain in the 1970s (London, Aurum, 2008)

SINGH, Gurharpal and SINGH TATLA, Darshan, Sikhs in Britain : the Making of a Community (London, Zeb Books, 2006).

\section{NOTES}

1. The European Social Charter (1961) Article 19 " The right of migrant workers and their families to protection and assistance" < http://polis.osce.org/library/f/2667/466/CoE-ITA-RPT-2667EN-466.pdf> consulted 12 September 2016. The European Social Charter applied to members of the European Council, which the UK joined as early as 1949, as a founding member.

2. The National Archives, Office for National Statistics, « Non-UK Born Census Populations 1951 - $2011 \quad$ - $\quad$ Full $\quad 20$ infographic $»$.<http:// 
webarchive.nationalarchives.gov.uk/20160105160709/http://www.ons.gov.uk/ons/rel/ census/2011-census-analysis/immigration-patterns-and-characteristics-of-non-uk-bornpopulation-groups-in-england-and-wales/non-uk-born-census-

populations-1951---2011---full-infographic.html > consulted 12 September 2016.

3. Dominic SANDBROOK, State of Emergency. The way we were: Britain 1970-1974, London, Penguin, 2011, p. 256.

4. Edward HEATH, The Course of My Life, London, Hodder and Stoughton, 1998, p. 455.

5. Andy Beckett goes so far as to suggest that both Heath and Wilson were "social democrats who believe[d] in big government". See "Heath vs Wilson - The 10 Year Duel" BBC 4, 2011 (my transcription) <https://www.youtube.com/watch?v=jYNcLJWylWU> consulted 13 September 2016.

6. John SOLOMOS, Race and Racism in Britain, Basingstoke, Macmillan, 1993, p. 69.

7. SOLOMOS, op.cit., p.68

8. The 1964 by-election at Smethwick provided a frightening illustration of the impact of immigration on the public and the electorate. The slogan of the Conservative candidate was: "If you want a nigger for a neighbour vote Liberal or Labour." Although Smethwick was a working class, Labour-voting constituency, the Tory candidate, whose entire campaign had revolved around immigration, won the election.

9. SANDBROOK, op.cit., p.254.

10. HEATH, op.cit., pp.455-456.

11. British passport holders from the Indian subcontinent (Gujaratis, frequently), whose parents or grandparents had taken part in the building of railways in imperial days, before going into business or farming locally.

12. This was not the first such crisis, as a similar one had occurred in 1968 in Kenya. Another one was to follow (albeit on a smaller scale) in 1976, in Malawi.

13. HEATH, op.cit., p. 457.

14. Ibid.

15. A right-wing, jingoistic club within the Conservative party. Created in 1961, ten years later it boasted 35 MPs, who lambasted Heath's moderate approach. Arguably, the Monday Club thrived under Heath, as he epitomised the post-war consensus and the one-nation approach that they loathed. The Monday Club became much quieter after Mrs Thatcher took over as Conservative leader (1975), as her strong views tended to converge with theirs on many matters, including immigration and race.

16. HEATH, op.cit., p. 457.

17. Quoted in Catherine PUZZO's unpublished PhD thesis, « Immigration Controls in Britain and France (1970-1986): A Comparative Study of Policy ", School of Language and International Studies, University of Surrey, 2000, p. 92.

18. PUZZO, op.cit., p.146.

19. Quoted in PUZZO, op.cit., p.143.

20. Ibid. (Source: House of Commons Hansard).

21. Gérard FUCHS, Ils resteront : le défi de l'immigration, Paris, Syros, 1987, p. 147-148.

Quoted in Vincent LATOUR, "Voluntary repatriation / Aide au retour volontaire : la question du retour des immigrés au Royaume-Uni et en France dans les années 1970" in Le Retour, edited by Laurent DORNEL, Pau, Presses Universitaires de Pau et des Pays de l'Adour, 2017 (page number unknown yet).

22. Email, 9 July 2015. Quoted in LATOUR, page number unknown yet.

23. HEATH, op.cit., p. 456.

24. Kenneth O MORGAN, Callaghan: A Life, Oxford, Oxford University Press, 1997, p.308. 
25. Ibid.

26. Roy JENKINS, speech before the National Committee for Commonwealth Immigrants (NCCI), 1966.

27. HEATH, op.cit., p.456.

28. Alwyn W. TURNER, Crisis? What Crisis ? Britain in the 1970s, London, Aurum, 2008, pp 205-225. p.219.

29. Although Wilson was only sixty when he resigned and lived for another nineteen years, he suffered from a form of early dementia.

30. "White Paper on Racial Discrimination" (PDF of the original document 1975) <http:// filestore.nationalarchives.gov.uk/pdfs/small/cab-129-184-c-93.pdf> consulted 14 September 2016.

31. «Race Relations Act 1976 (Repealed)» <http://www.legislation.gov.uk/ukpga/1976/74/ section/3> consulted 14 September 2016.

32. Jack HOWARD-DRAKE, Assistant Secretary, Home Office in Playing the Race Card, BBC 2, 1999 (my transcription). <https://www.youtube.com/watch?v=UMa1Zht0934> consulted 20 September 2016.

33. BECKETT, op.cit., p.444.

34. BECKETT, op.cit., p.445.

35. William MACPHERSON, Report of an Inquiry by Sir William Macpherson of Cluny Presented to Parliament by the Secretary of State for the Home Department by Command of Her Majesty, London, February 1999, <https://www.gov.uk/government/uploads/system/uploads/ attachment_data/file/277111/4262.pdf> consulted 15 September 2016.

36. TURNER, op.cit., p. 215.

37. "Notting Hill Carnival ends in riot", BBC News, 30 August 1976, <http://news.bbc.co.uk/ onthisday/hi/dates/stories/august/30/newsid_2511000/2511059.stm> consulted 20 September 2016.

38. TURNER, op.cit., pp. 216-217.

39. TURNER, op.cit., p. 217.

40. TURNER, op.cit., pp. 217-18.

41. TURNER, op.cit., pp. 220.

42. < https://www.legifrance.gouv.fr/jo_pdf.do?id=JORFTEXT000000864827 > consulted 20 September 2016.

43. See for example TURNER, op.cit., pp 205-225.

44. Margaret THATCHER, TV Interview for Granada World in Action, 27 January 1978. Transcript available on the Margaret Thatcher Foundation website < http://www.margaretthatcher.org/ document/103485> consulted 20 September 2016.

45. SOLOMOS, op.cit., p. 207

46. SOLOMOS, op.cit., p. 206

47. Gurharpal SINGH and Darshan SINGH TATLA, Sikhs in Britain: the Making of a Community, London, Zeb Books, 2006, p. 143.

48. TURNER, op.cit., pp 218-219.

49. Dominic SANDBROOK, Seasons in the Sun. The Battle for Britain, 1974-1979, London, Penguin, 2013, pp. 599-600.

50. BECKETT, op. cit., p. 360.

51. BECKETT, op.cit., p. 394.

52. SANDBROOK, op.cit., p. 382.

53. SOLOMOS, op.cit., p. 69 


\section{ABSTRACTS}

The vision of the 1970s tends to be dominated by the notions of crisis and decline. However the 1970s were also characterised by a number of experiments, sometimes failures but also sometimes successes, which contributed to shaping late 20th and early 21st century Britain. It is the aim of this article to establish and document to what extent this applies to immigration and integration.

La vision dominante des années 1970 au Royaume-Uni est celle d'un pays en crise et en déclin. Néanmoins, cette décennie fut également marquée par nombre d'expérimentations, d'échecs mais aussi parfois de succès, qui ont contribué à façonner la société britannique de la fin du 20 ème et le début du 21ème siècles. Cet article entend démontrer et illustrer dans quelle mesure ce constat s'applique également aux questions de l'immigration et de l'intégration.

\section{INDEX}

Keywords: immigration, integration, racism, 1970s

Mots-clés: Immigration, racisme, intégration, années 1970

\section{AUTHOR}

\section{VINCENT LATOUR}

Université Toulouse - Jean Jaurès

CAS (EA 801) 